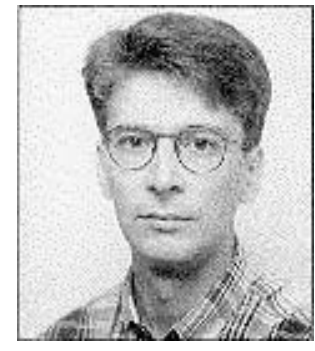

Janne Matikainen

\title{
Koulutuksen laatu organisaatiokulttuurisesta näkökulmasta
}

\section{Tiimiorganisoitu koulutus ei välttämättä takaa koulutuksen laatua. Todennäköisesti se kuitenkin kohentaa sitä, koska hyvän ja laadukkaan oppimisen kriteerit edellyttävät opettajien yhteistyötä. Opettajien tiimityö ei sinällään ole koulutuksen laatua, vaan keino laadun tavoittelussa.}

Koulutuksen laatu on noussut yhdeksi 1990 luvun koulutuskeskustelun keskeisimmäksi teemaksi. Erityisesti on keskusteltu koulutuksen laadun määrittelemisestä sekä erilaisten laatumallien, kuten TQM:n eli kokonaisvaltaisen laatujohtamisen, sovellettavuudesta koulutukseen (ks. esim. Ståhle 1993). Laatu-käsitteelle on perinteisesti ollut leimallista teknisyys ja tilastollisuus (Sarala \& Sarala 1996).

Laatukeskustelussa on vallinnut melko suuri yksimielisyys siitä, että teknisluontoiset laatukäsitykset eivät ole suoraan siirrettävissä koulutukseen, vaan koulutus vaatii oman, erityisen laatumääritelmänsä. Eräs näkökulma laadun määrittelyssä ja kehittämisessä on organisaatiokulttuurin muutos. Tämä varsin tärkeä näkökulma on toisinaan jäänyt laatukeskustelussa hiukan taka-alalle. Tässä artikkelissa painotetaan organisaatiokulttuurinäkökulmaa koulutuksen laadun kehittämisessä. Artikkelin aluksi luodaan katsaus organisaatiotutkimuksen paradigmamuutokseen ja organisaatiokulttuu- rin käsitteeseen. Tämän jälkeen esitellään yksi mahdollisuus koulutuksen laadun määrittelyssä sekä pohditaan organisaation syvällistä muutosta. Lopuksi koulun organisaatiokulttuuria tarkastellaan empiirisestä näkökulmasta.

\section{Organisaatiotutkimuksen paradigmamuutos}

Organisaatiotutkimuksen vallitsevana paradigmana on toisen maailmansodan jälkeen ollut systeemirationalismi (Silén 1995, 11). Systeemirationalismi oli koulukuntana melko hajanainen, mutta yhteistä systeemirationalismin edustajille oli inhimillisten tekijöiden väheksyminen. Sekä käytännölliset konsultit että akateemiset tutkijat kritisoivat systeemirationalismia ja tilalle nousi organisaatiokulttuurin tutkimus, erityisen voimakkaasti 1980-luvulla (Alvesson \& Berg 1988). Organisaatiokulttuurin tutkimus ja käytännön konsultointi ottavat huomioon myös organisaation irrationaaliset tekijät, kun taas systeemiteoria keskittyi pelkästään ratio- 
naalisiin tekijöihin (Juuti \& Lindström 1995, 72). Organisaatiokulttuurisessa viitekehyksessä johtajien toiminnassa korostetaan nimenomaan johtajuutta (leadership) liikkeenjohdon (management) sijaan, koska todellisen johtajuuden katsotaan parantavan ihmisten sitoutumista, tehostavan työskentelyä sekä lisäävän sisäistä motivaatiota, jolloin kontrollin tarve vähenee. Kaiken kaikkiaan organisaatiotutkimuksessa kiinnostuttiin systeemikaavion (input, output, feedback jne.) sijasta organisaation säännöistä, normeista, perusoletuksista, symboleista, ja kulttuuristen tekijöiden suhteesta organisaation taloudelliseen tuottavuuteen ja kannattavuuteen (Alvesson 1991, 188). Organisaatiotutkimuksessa on siis tapahtunut selkeä paradigmamuutos ja organisaatiokulttuurin tutkimus on 1990-luvullakin osoittautunut elinvoimaiseksi teemaksi (Kekäle 1993, 320). Organisaatiokulttuurin tutkimus on yritysten lisäksi laajentunut mm. terveyskeskuksiin (Kinnunen 1990), yliopistoihin (Kekäle 1997) ja kouluihin (Matikainen, tulossa).

Organisaatiokulttuuri on paradigmana kuitenkin hyvin hajanainen. Keskeinen vedenjakaja organisaatiokulttuuristen koulukuntien kesken on se, nähdäänkö organisaatio kulttuurina (organization is a culture) vai kulttuuri organisaation yhtenä muuttujana (organization has a culture) (Kinnunen 1990, 16-17). Nämä pääsuuntaukset jakautuvat vielä useisiin koulukuntiin, riippuen esimerkiksi siitä, painotetaanko organisaation symbolijärjestelmiä tai tietojärjestelmiä (Juuti 1994, 20). Tässä yhteydessä ei ole mahdollista paneutua syvällisesti organisaatiokulttuuriparadigman hajanaisuuteen. Olennaista on huomata, että yhtenäistä organisaatiokulttuuriteoriaa ei ole olemassa.

Lukuisista koulukunnista johtuen organisaatiokulttuurin määritteleminen on vaikeaa, ja tuskin kaikkia tyydyttävää määritelmää on löydettävissäkään. Tunnetuin lienee Scheinin esittämä määritelmä, joka on myös suhteellisen onnistunut:

Organisaation kulttuurilla tarkoitetaan perusoletusten mallia, jonka jokin ryhmä on luonut tai kehittänyt oppiessaan käsittelemään ulkoiseen sopeutumiseen tai sisäiseen yhdentymiseen liittyviä ongelmiaan. Tätä mallia ryhmä pitää perusteltuna ja siksi opettaa sitä uusille jäsenille oikeana tapana havaita, ajatella ja tuntea.

(Schein 1987, 26)

Organisaatiokulttuuri on siis teoria tai malli, jonka pohjalta organisaatiossa olevat ihmiset käyttäytyvät ja jäsentävät maailmaa. Tämä malli tai teoria on organisaatiolle ja sen jäsenille suurelta osin piilevä ja itsestäänselvä. Olennainen kysymys organisaatiokulttuurin määrittelemisessä ja tutkimisessa on kulttuurin yhtenäisyys tai hajanaisuus. Organisaatiokulttuurin tutkimuksessa erotetaankin seuraavat näkökulmat (Frost et al. 1991; Kekäle 1993):

- Integraationäkökulma korostaa pääasiallisesti selkeyttä ja yhdenmukaisuutta kulttuurin eri ilmentymien välillä.

- Differentaationäkökulma painottaa kulttuuristen ilmentymien ristiriitaisuutta ja yhteensopimattomuutta.

- Fragmentaationäkökulman mukaan monimerkityksisyys on väistämätön ja läpitunkeva nykyelämän piirre.

Eri näkökulmat vaikuttavat ratkaisevasti siihen, millaisena organisaatiokulttuurin hahmotamme. Toisaalta myös tutkimuskohde määrää sitä, mikä näkökulma on sopivin. Scheinin organisaatiokulttuurimääritelmä ja -teoria painottaa ensisijaisesti integraationäkökulmaa, mutta ottaa myös huomioon kulttuurin mahdollisen ristiriitaisuuden ja hajanaisuuden.

Organisaatiokulttuurin tutkimus on keskittynyt yrityksiin, mistä johtuu yleinen nimitys, yrityskulttuuri. Koulutusorganisaatioita tutkittaessa puhutaan tavallisesti koulukulttuurista. Koulun organisaatiokulttuuri ja koulukulttuuri ovat sisällöllisesti hyvin läheisiä, joten kyseessä on lähinnä vivahde-ero. Koulun organisaatiokulttuuri liittyy lähtökohdiltaan organisaatiotutkimukseen ja sosiaalipsykologiaan, kun taas koulukulttuurin lähtökohdat ovat kasvatustieteelliset (ks. esim. Syrjäläinen 1994). Ongelmana molemmissa käsitteissä on sana koulu, joka 
viittaa vahvasti peruskouluun. Tällöin ulkopuolelle jäävät esimerkiksi keskiasteen oppilaitokset ja vapaan sivistystyön koulutusorganisaatiot. Olisikin ehkä oikeampaa puhua koulutuskulttuurista. Tässä artikkelissa käytän nimitystä koulun organisaatiokulttuuri, jolla haluan painottaa organisaatioteoreettista näkökulmaa.

\section{Koulutuksen laatu ja organisatoriset paradigmat}

Koulutuksen laatu on hyvin monitahoinen ilmiö. Keskeistä koulutuksen laadussa on oppiminen: Laadukkaan koulutuksen pitää tuottaa oppimista. Koulutuksen laadun ongelma ei ratkea tällä määritelmällä, vaan ongelma siirtyy kysymykseen, mitä on hyvä ja laadukas oppiminen? Hyvälle ja laadukkaalle oppimiselle voidaan asettaa seuraavat kriteerit (Sahlberg \& Leppilampi 1994, 28-29):

- konstruktiivisuus: oppija luo ja käsittelee tietoa aktiivisesti kognitiivisten prosessien avulla

- kumulatiivisuns: uuden oppiminen perustuu aiemmin opittuun

- itseohjantuvuns: oppija ymmärtää ja hallitsee omaa toimintaansa

- tavoitesuntautuneisuus: oppija ymmärtää ja sisäistää oppimisen tavoitteet ja merkityksen

- tilannesidonnaisuus: oppiminen paranee, kun se liittyy oppijan elämismaailmaan

- ybteistoiminnallisuus: dialogi ja sosiaalinen vuorovaikutus edistävät yhteisen sosiaalisen todellisuuden ja merkitysten rakentumista.

Esitetyt laadukkaan oppimisen kriteerit eivät ole ongelmattomia, mutta niitä voidaan pitää tässä yhteydessä lähtökohtaoletuksina. Oppiminen koulutuksen tuloksena on perusteltua yksilön, koulutuksen järjestäjän ja yhteiskunnan näkökulmasta. On periaatteessa kaikkien edun mukaista, että oppijoissa tapahtuu oppimista.

Koulutuksen laadun määrittely oppimisena tarkoittaa sitä, että muun toiminnan täytyy tukea oppimista, jotta se voidaan määritellä osaksi koulutuksen laatua. Tällöin opetusmenetelmät, opettajan tai kouluttajan ammattitaito, opettajien tiimityö tai oppijoiden ja opettajien itsearviointi ovat keinoja oppimisen tehostamises- sa eli koulutuksen laadun parantamisessa. Tiimiorganisoitu koulutus ei siis välttämättä takaa koulutuksen laatua, mutta se todennäköisesti kohentaa sitä, koska edellä mainitut hyvän ja laadukkaan oppimisen kriteerit edellyttävät opettajien yhteistyötä. Opettajien tiimityö ei sinällään ole koulutuksen laatua, vaan keino sen tavoittelussa.

Asiakkuus ja asiakastyytyväisyys ovat laadun ja siis myös koulutuksen laadun keskeisiä elementtejä. Edellä määritelty laadukas oppiminen ottaa huomioon asiakasnäkökulman. Kun on kyse koulutuksesta, on toisinaan kuitenkin vaikea määritellä, kuka on asiakas: oppijat, koulutuksen rahoittaja, yhteiskunta vai kenties nuorten oppilaiden vanhemmat? Laadukkaassa koulutuksessa on lähdettävä siitä, että asiakkaita ovat oppijat ja koulutuksen tulee ensisijaisesti hyödyttää heitä.

Ongelmana tässä näkökulmassa on asiakastyytyväisyys. Oppija (eli asiakas) ei välttämättä ole tyytyväinen, vaikka hän oppisi. Oppiminen saattaa tuottaa epävarmuutta ja ahdistusta. Voisiko siis joku oppijan ulkopuolelta määritellä, mikä on hänelle hyödyksi? Näin varmasti on esim. yleissivistävässä koulutuksessa, jossa yhteiskunta määrittelee melko pitkälle oppimisen tavoitteet. Kuitenkin yleissivistävässäkin koulutuksessa olisi oppilaat nähtävä asiakkaina, mikäli ollaan kiinnostuneita laadun kehittämisestä.

Käsitys koulutuksen laadusta riippuu myös organisaatioteoreettisesta näkökulmasta. Koulutuksen laatua on usein tarkasteltu systeemisestä näkökulmasta. Tämä johtunee TQM:n ja systeemirationalismin sekä historiallisesta että sisällöllisestä kytkennästä. TQM on kuitenkin luonteeltaan teknistä ja perustuu taloudellisiin ja tilastollisiin mittareihin (Silén 1995). Siten sen soveltaminen koulutukseen on monilta osin ongelmallista. Luonnollisesti TQM:ssa on koulutuksen laadun kannalta relevanttejakin piirteitä, kuten asiakaskeskeisyys ja tiimityö.

Systeeminäkökulman painottumiseen liittyy kuitenkin ongelmia, koska systeeminäkökulma 
pitää yllä laadun teknistä luonnetta. Tämä ongelma on tuotu esille TQM:n yhteydessä (Ståhle 1993, 237). Voidaan sanoa, että systeemiteoria pitää yllä laadun kvantitatiivista aspektia, mikä tarkoittaa erilaisten määrällisten mittareiden, standardien ja raporttien käyttöä. Koulutuksessa tämä laatukäsitys on ongelmallinen, koska koulutuksen laatua on vaikea operationalisoida objektiivisesti mitattaviksi ja vertailukelpoisiksi yksiköiksi.

Systeemiteorian kritiikissä on muistettava, että organisaatiokulttuurinäkökulma ei tarjoa täsmällistä ja valmista ratkaisua koulutuksen laadun ongelmaan. Tämä johtuu siitä, että organisaatiokulttuuriteoria on organisaation kehittämisen näkökulma, joka syventää laatukeskustelua, mutta ei kykene vastaamaan kysymykseen, mitä laatu on.

Organisaatiokulttuurinäkökulma syventää laatukäsitteiden merkitystä sekä monipuolistaa keinoja laadun kehittämisessä. Koulutuksen laadun tarkastelua organisaatiokulttuurisesta näkökulmasta vaikeuttaa se, että jokaisella organisaatiolla on ainutlaatuinen kulttuurinsa. Tällöin yhteisen ja yksimielisen laatumääritelmän löytäminen lienee mahdotonta. Koulutuksen ja yleisestikin laadun määrittelyssä olisikin ehkä standardien etsimisen sijaan tyydyttävä laadun moniselitteisyyteen ja moniarvoisuuteen.

\section{Kohti laatua: organisaatiokulttuurin muutos}

Kuten aiemmin on tullut esille, koulutuksen laadun kehittäminen on ensisijaisesti organisaation kehittämistä ja organisaatiokulttuurin muutosta. Toisin sanoen laatua ei voi saavuttaa ilman organisaatiokulttuurin muuttamista. Tämän vuoksi koulutuksen laadun tarkastelussa on puututtava organisaatiokulttuurin muutoksen mahdollisuuksiin ja rajoituksiin.

Organisaatiokulttuuria on usein pidetty organisaation yhtenä muuttujana, jolloin organisaatiokulttuurin muutoksesta saadaan selkeä mutta myös pinnallinen käsitys. Sen sijaan or- ganisaation mieltäminen kulttuuriksi lisää muutoksen onnistumisen mahdollisuutta, koska organisaatiokulttuurin muutos vaikuttaa kaikkialla organisaatiossa, kuten opetuksessa, työn organisoinnissa sekä työn ja oppimisen arvioinnissa. Laatukeskustelu on kuitenkin jättänyt vähemmälle huomiolle laatujärjestelmän käytännöllisen ja teoreettisen soveltamisen eli organisaation muutoksen (ks. esim. Aikuiskasvatus 4/1993).

Organisaation syvällinen muutos voidaan erottaa perinteisestä organisaation kehittämisestä käsitteillä ensi asteen muntos ja toisen asteen muntos (Juuti \& Lindström 1995, 25-31). Ensi asteen muutos tarkoittaa tietyn kulttuurisen viitekehyksen sisällä tapahtuvaa kehittymistä ja oppimista. Ensi asteen muutos viittaa pinnalliseen muutokseen, jossa arvot, normit, merkitykset ja oletukset eli lyhyesti sanottuna kulttuuri pysyy entisenlaisena. Ensi asteen muutos on kuitenkin monessa tapauksessa riittämätön, koska organisaatioiden toimintaympäristöt muuttuvat nopeasti ja perusteellisesti. Tämän vuoksi on alettu puhua toisen asteen muutoksesta, jolla viitataan koko kulttuurisen viitekehyksen muuttumiseen. Kulttuurisen viitekehyksen muuttuminen tarkoittaa ajattelu- ja toimintatapojen perusteellista muuttumista. Taulukossa 1 on tarkasteltu ensi asteen ja toisen asteen muutoksia.

Koulutuksen laadun kehittämisessä on monessa tapauksessa kyse toisen asteen muutoksesta. Tätä ei voida yleistää koskemaan kaikkia koulutuksen sektoreita ja oppilaitoksia. Uskon kuitenkin, että suurimmassa osassa oppilaitoksia ja muita koulutuksen instituutioita kulttuurisen viitekehyksen täytyy muuttua, ennenkuin organisaatioiden kulttuurissa on havaittavissa laadun tunnusmerkkejä. Pelkkien laatutermien ja kosmeettisten muutosten perusteella ei voida puhua organisaatiokulttuurin muutoksesta laadun suuntaan. On kuitenkin oltava varovainen, ettei toisen asteen muutosta pidetä hyvänä ja ensi asteen muutosta huonona. Molempia muutoksia tarvitaan ja riippuu täysin tilanteesta, kumpaa tyyppiä tarvitaan. Organisaation muutosprosessissa on hyödyllistä erottaa ensi 


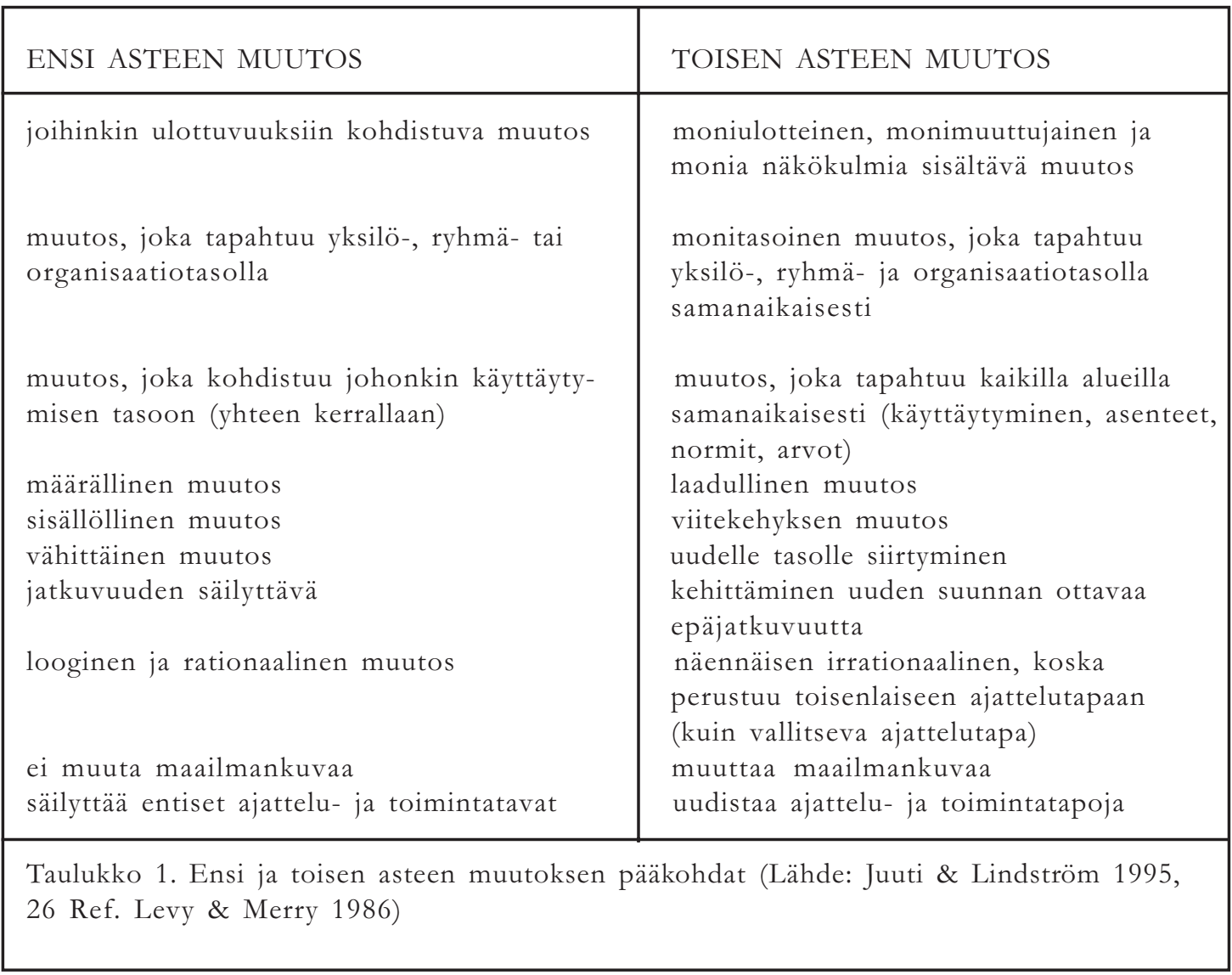

ja toisen asteen muutokset, mutta näitä tyyppejä ei tulisi arvottaa.

Systeemiteoriaa on kritisoitu siitä, että sen avulla ei ole saavutettu toisen asteen muutoksia (Juuti \& Lindström 1995, 142), sekä positivistisesta tutkimustraditiosta, tehottomuudesta organisaatioiden muutoksessa ja teoreettisen pohjan kapeudesta (Alvesson \& Berg 1988, 2225). Lisäksi systeemiteorian lähtökohtiin kuuluu kausaalinen selittäminen, joka on varsin ongelmallinen lähtökohta inhimillisen toiminnan selittämisessä, mikä näkyy $\mathrm{mm}$. Sengen (1990) teoksessa, sillä hänen useimmat esimerkkinsä liittyvät luontoon, liiketalouteen tai kilpavarusteluun. Syntyy kuva, että systeemiteoreettinen näkökulma on ulkokohtainen ja objektiivinen. Sen avulla ei saavuteta organisaatioiden elämän rikkautta ja vaihtelevuutta. Kulttuurinäkökulma on puolestaan kiinnostu- nut elämän rikkaudesta organisaatioissa: merkityksistä, sosiaalisista suhteista, perinteistä, kielestä ja toiminnasta. Olisi kuitenkin hedelmätöntä asettaa systeemiteoriaa ja organisaatiokulttuurinäkökulmaa vastakkain. Kummallakin näkökulmalla on omat vahvuutensa. Systeemiteorian vahvuus on kokonaisuuksien hahmottaminen ja hallitseminen. Tämän lisäksi tarvitaan syvällistä näkökulmaa organisaation sisälle, sen kulttuuriin.

Organisaatiokulttuurinäkökulma on pääasiassa teoreettinen tapa jäsentää organisaatioita, mutta se antaa myös viitteitä siitä, millaisia käytännön muutostoimien tulisi olla. Tässä yhteydessä en puutu organisaatiokulttuurin käytännöllisiin muutoskeinoihin, mutta nyrkkisääntönä voitaneen pitää muutoskeinojen monipuolisuutta ja kokonaisvaltaisuutta. 


\section{Esimerkki koulun organisaatiokulttuurista}

Tutkimuskohteenani (Matikainen, tulossa) oli kaksi peruskoulun ala-astetta, joten tutkimukseni tarjoaa konkreettisen esimerkin koulun tai oppilaitoksen organisaatiokulttuurista. Lisäksi toisen tutkimuskoulun osalta voidaan puhua organisaatiokulttuurin muutoksesta.

Tutkimuskoulut poikkesivat toisistaan julkiselta kuvaltaan. Toinen oli melko perinteinen koulu, toinen taas "uudistuksellinen". Tutkimustehtävänäni oli selvittää, onko koulujen organisaatiokulttuurissa havaittavissa eroja. Tutkimukseni teoreettisena viitekehyksenä oli Scheinin (1987) organisaatiokulttuuriteoria, jossa kulttuurin ydin on perusoletukset. Perusoletukset syntyvät kun organisaatio kohtaa ulkoiseen sopeutumiseen ja sisäiseen yhdentymiseen liittyviä ongelmia. Perusoletusalueita on kaikkiaan viisi:

1. Subde ympäristöön (toiminta-ajatus, identiteetti, yhteiskunnallinen funktio, merkityksellinen ympäristö)

2. Totuuden ja todellisuuden luonne (totuuden kriteerit, ajan ja tilan luonne)

3. Ibmisluonto (hyvä ja kehityskelpoinen, paha ja muuttumaton tai neutraali)

4. Ibmisen toiminnan luonne (suuntautunut tekemiseen tai olemiseen)

5. Ibmisten välisten subteiden luonne (perinne ja hierarkia, rinnakkaisuus tai kilpailu).

Tutkimusmenetelmänäni oli haastattelu. Metodologinen asetelma oli kaksivaiheinen. Ensimmäisellä haastattelukierroksella haastatteluissa käytiin läpi monenlaisia asioita, kuten opettajien työpäivää, yhteistyötä, opetus- ja oppimismenetelmiä, arviointia, suhdetta vanhempiin ja muihin sidosryhmiin. Ensimmäisellä kierroksella haastattelin toisesta koulusta rehtoria ja kahta opettajaa ja toisesta koulusta rehtorin lisäksi kolmea opettajaa. Haastattelut kestivät keskimäärin 1,5 tuntia. Ne nauhoitettiin ja purettiin nauhalta kirjoittamalla ne sanatarkasti. Haastattelut on analysoitu Scheinin esittämien sisäiseen yhdentymiseen ja ulkoiseen sopeutumiseen liittyvien ongelmien pohjalta. Scheinin esittä- miä ongelma-alueita muotoiltiin joiltain osin kouluun sopivammiksi. Tämän kierroksen analyysin pohjalta muotoilin kultakin ongelma-alueelta väittämän, joka mahdollisimman hyvin kuvaisi kyseistä koulua. Toisella haastattelukierroksella esitin väittämät haas-tateltaville, jotka saivat kommentoida analyysin tuloksia. Esimerkiksi opettajien ja oppilaiden välisiä suhteita kuvaavat väittämät olivat seuraavanlaisia:

Opettaja ja oppilas ovat melko tasa-arvoisia ja kykenevät tekemään samanlaisia töitä (suunnittelu, arviointi yms.). (uusi koulu)

- Oppilailla on vastuu omasta työstään ja opettajat vastaavat ja määräävät kaikesta muusta. (vanha koulu)

Väittämiä oli kaikkiaan 11 koulua kohden. On huomattava, että väittämien funktiona ei ollut yksin kuvata koulua, vaan provosoida haastateltavia. Tavoitteena oli tuottaa puhetta, ei pelkästään testata väitteiden oikeellisuutta. Toisella haastattelukierroksella haastattelin kummastakin koulusta rehtoria ja kolmea opettajaa. Kukin haastattelu kesti noin tunnin. Nauhoitus ja purkaminen tapahtui kuten ensimmäisellä kierroksella. Toisen kierroksen analyysi keskittyi informanttien esittämiin perusteluihin.

Vesala (1996) käytti yrittäjyystutkimuksessaan vastaavaa metodia, jota hän nimittää kvalitatiiviseksi asennetutkimukseksi. Organisaatiokulttuurin tutkimuksessa on hiukan ongelmallista käyttää asenteen käsitettä, mutta metodisesti asetelma on samanlainen. Olennaista haastateltavien puheessa ovat asenteet tai perusolettamukset ja niille esitettävät perustelut, ei niinkään informanttien määrä tai edustavuus. Analyysi kohdistui informanttien tuottamaan puheeseen ja puheessa ilmeneviin luokituksiin, oletuksiin ja käsityksiin.

Tutkimuksessa ilmeni, että koulujen organisaatiokulttuurissa oli eroja. Seuraavassa havainnollistan koulujen organisaatiokulttuuria haastateltavien kommenteilla. Tulkintoja ja johtopäätöksiä ei ole tehty pelkästään esitettyjen kommenttien varassa, vaan kommentit ovat tässä yhteydessä esimerkkeinä. 
Perinteisemmän koulun organisaatiokulttuuri oli monilta osin ennakko-odotusten mukainen. Koululla ei ollut selkeää toiminta-ajatusta, vaan koulu toimi perinteiden ohjaamalla tavalla, jolloin toimintaa leimasi laitosmaisuus:

"Minusta täällä oli laitosmainen tunnelma." Oppikirjojen asema opetuksessa oli keskeinen, vaikeakin niiden rooli oli pienenemässä: "Seuraan kirjoja aika paljon."

"Kirja kertoo mitä pitäis tehdä."

Opettajat työskentelivät melko yksin omassa luokassaan:

"Toki tässä koulussa on semmosia ibmisiä, jotka tekee aktiivisesti ybteistyötä, mutta se on vähemmistö."

Ihmissuhteet olivat etäisiä ja opettajilla oli ehdoton valta-asema oppilaisiin nähden:

"Nimenomaan tämä opettajien välinen ybteistyö ei vielä kovin vilkasta ole."

"Aikuisilla täytyy olla lopullinen määräysvalta."

Mainittakoon, että kyseisessä koulussa oli meneillään muutosprosessi, joten koulun organisaatiokulttuuri on saattanut muuttua tutkimusajankohdan jälkeen.

Uudenaikaisempi koulu erosi perinteisestä koulusta monessa suhteessa. Koulussa oli yhteisesti pohdittu toiminta-ajatus, joka oli kaiken toiminnan pohjana. Toiminta-ajatuksessa on keskeistä oppilaskeskeisyys:

"Oppilaskeskeisyys on ollu meillä oi-
keestaan koko tän kouluajan semmonen
punanen lanka." Oppilaskeskeisyys ilmenee myös käytännön työskentelyssä:

"Oppilaat saa itte päättää missä tabdissa nää etenee."

"Tää on työympäristö lapselle koko koulu." Toiminta-ajatuksessa korostun myös koulun ybteinen pedagoginen näkemys:

"Se (koulun oma teoria) on tämmönen oman aktivaation ja oman käyttäytymisen, siis tämmösen tiedonhankinnallisen toiminnan teoria."

Opettajien työskentely on organisoitu tiimeiksi, joita tosin nimitetään työyksiköiksi:

"Toimintaa suunnitellaan ja toteutetaan byvin pitkälle työyksiköissä.”
Sekä opettajien että oppilaiden arvioinnissa korostuu itsearviointi:

"Kyl kaikki parhaat arviointiprosessit lähtee siitä tekijästä."

Uudenaikaisempi koulu ei tietystikään positiivisista asioista huolimatta ollut mikään paratiisi. Esimerkiksi opettajien tiimityö lisäsi klikkiytymistä ja opettajien välisiä ristiriitoja.

Kiteytin koulujen organisaatiokulttuurin Scheinin esittämiin viiteen perusoletukseen. Taulukossa 2 (sivulla 216)on tiivistettynä koulujen perusolettamusten keskeisimmät sisällöt.

Suurimmat eroavaisuudet koulujen perusoletuksissa ilmenivät toiminta-ajatuksessa, totuuden ja ajankäytön luonteessa sekä ihmissuhteiden luonteessa. Suurimmat yhtäläisyydet ilmenivät oletuksissa ihmisluonnossa ja ihmisen toiminnan luonteessa. Myös tilankäytössä oli yhtäläisyyksiä.

Tutkimuksessa painottui Scheinin teorian mukaisesti integraationäkökulma, minkä vuoksi koulujen organisaatiokulttuurista välittyi ehkä liiankin yhtenäinen kuva. Kummassakin koulussa oli havaittavissa ristiriitaisia ja hajanaisia kulttuurisia ilmentymiä, joiden systemaattinen tutkiminen olisi vaatinut lisäaineistoja sekä monipuolisempia tutkimusmenetelmiä.

Uudenaikaisemmassa koulussa oli havaittavissa monia laadukkaan koulutuksen tunnusmerkkejä: oppilas- eli asiakaskeskeisyys, pedagogisesti perusteltu toiminta-ajatus sekä yhteiset suunnittelu- ja arviointiprosessit. Sen sijaan perinteisemmässä koulussa ei ollut havaittavissa suuressa määrin asiakkaan oppimista huomioivaa laatua. Esimerkkinä koulutuksen laadusta tarkastelen tutkimuskoulujeni oppilasarviointikäytäntöjä. Molemmissa kouluissa ilmaistiin eksplisiittisesti jatkuvan arvioinnin ja itsearvioinnin tärkeys. Käytännössä kuitenkin perinteisemmässä koulussa käytettiin opettajan antamaa sanallista ja numeroarviointia:

"Nyt pubutaan itsearvioinnista et oppilaiden pitäis itseään arvioida. En mä tiedä mitä pystyy itseään arvioimaan."

Uudenaikaisemmassa koulussa arviointi oli 


\begin{tabular}{|l|l|l|}
\hline PERUSOLETUS & UUDENAIKAISEMPI KOULU & PERINTEINEN KOULU \\
\hline Suhde ympäristöön & $\begin{array}{l}\text { - Toiminta-ajatus: viestintäkasvatus } \\
\text { ja tiedonhankinta } \\
\text { - Tehtävä on opettaa lapsia selviyty- } \\
\text { mään elämässä ja yhteiskunnassa. }\end{array}$ & $\begin{array}{l}\text { - Toiminta-ajatus on } \\
\text { selkiytymättä } \\
\text { - Tehtävä on kasvattaa } \\
\text { kelpo kansalaisia }\end{array}$ \\
\hline $\begin{array}{l}\text { Todellisuuden, ajan ja } \\
\text { paikan luonne }\end{array}$ & $\begin{array}{l}\text { - Totuus on pragmaattinen. } \\
\text { - Aikaa ja tilaa käytetään tehtävien } \\
\text { mukaan, jokaisella opettajalla tosin } \\
\text { oma reviiri, luokkatila. }\end{array}$ & $\begin{array}{l}\text { - Totuus nojaa perinteisiin. } \\
\text { töihin, tilankäyttö perustuu } \\
\text { reviireihin. }\end{array}$ \\
\hline Ihmisluonto & $\begin{array}{l}\text { Ihmiset ovat pääosin hyviä ja } \\
\text { kehityskelpoisia }\end{array}$ & $\begin{array}{l}\text { Ihmiset ovat neutraaleja, } \\
\text { osa ihmisistä ovat hyviä } \\
\text { ja kehityskelpoisia, osa ei. }\end{array}$ \\
\hline $\begin{array}{l}\text { Ihmisen toiminnan } \\
\text { luonne }\end{array}$ & $\begin{array}{l}\text { Ihmiset ovat pääasiassa } \\
\text { toimintaan suuntautuneita. }\end{array}$ & $\begin{array}{l}\text { Ihmiset ovat olemiseen, } \\
\text { mutta yhä enemmän myös } \\
\text { toimintaan suuntautuneita. }\end{array}$ \\
\hline Ihmissuhteiden luonne & $\begin{array}{l}\text { - Perustana on rinnakkaisuus ja } \\
\text { yhteistyö. } \\
- \text { Vallankäyttö on osallistuvaa ja } \\
\text { delegoivaa. }\end{array}$ & $\begin{array}{l}\text { - Perustana ovat perinteet } \\
\text { ja hierarkia. } \\
\text { - Vallankäyttö on holhoavaa. }\end{array}$ \\
\hline Taulukko 2. Koulujen & \begin{tabular}{l} 
organisaatiokulttuuri tiivistettynä perusoletusten muodossa. \\
\hline
\end{tabular} \\
\hline
\end{tabular}

opettajan, oppilaan ja vanhempien välistä, jatkuvaa yhteistyötä:

"Oppilas arvioi oman työskentelynsä, vanhemmat arvioi sen jakson työstön ja opettaja antaa siitä vielä arvion."

Uudenaikaisemman koulun oppilasarvioinnissa näkyi itseohjautuvuuden, tavoitesuuntautuneisuuden ja yhteistoiminnallisuuden periaate (ks. edellä laadukas oppiminen). Arviointikäytännöt siis tukivat laadukasta oppimista. Perinteisemmässä koulussa tuskin saavutetaan monipuolisempia arviointimuotoja, ennenkuin koulun organisaatiokulttuurissa tapahtuu muutoksia. Toisin sanoen arvioinnin taustalla olevat perusoletukset pitää tuoda esille ja pyrkiä muuttamaan, jotta toimintatavoissa ilmenee todellisia muutoksia. On kuitenkin syytä huomata, että perinteisenkin koulun oppilasarvioinnissa oli laadun tunnusmerkkejä, mutta vähemmän kuin uudenaikaisemman koulun arviointikäytännöissä.

Tutkimukseni perusteella voidaan tehdä myös joitain havaintoja organisaatiokulttuurin muutoksesta, vaikka se ei varsinaisesti tutkimuskohteenani ollutkaan. Tutkimuskouluistani uudenaikaisempi on esimerkki organisaation toisen asteen muutoksesta, sillä koulu erottui perinteisemmästä koulusta, joka todennäköisesti edustaa traditionaalista luokkahuonekeskeistä koulua. Uuden koulun toisen asteen muutos ilmenee seuraavista seikoista:

Koulussa on keskeistä opettajien, tiimityön ja organisaation kehittäminen, joten muutosta tapahtuu yksilö-, ryhmä- ja organisaatiotasolla:

"Toimintaa suunnitellaan ja toteutetaan byvin pitkälle työyksiköissä."

"Omat virbeensä näkee parbaiten siinä kun laittaa videokameran nurkkaan ja kattoo sit sen videonauban."

"No työybteisön arviointia oli tänä aamuna viimeks eli meille annettiin (rebtori antoi monisteita, joissa piti erilaisia asioita arvioida, oliko mennyt hyvin vai huonosti."

Koulussa on irtauduttu monista perinteisen koulun toiminta- ja ajattelutavoista. Esimerkiksi 
rahat on budjetoitu opettajakohtaisesti. Oppikirjojen asema on kyseenalaistettu:

"Ja sitte tietysti mikä se oppikirja on, niin

sillä lailla vähän kyseenalaista ... jossa-

kin opetellaan lukemaan aapisesta, toisessa sanomalebdestä."

Opettajan kaikkitietävä asema on kyseenalaistettu:

"Lapset on paljon oppivaisempia (kuin opettajat)."

Lisäksi koulussa on monia perinteiselle koululle vieraita käytäntöjä, kuten oppilaiden liukuva työaika.

Koulu on ottanut uuden suunnan, joka vaikuttaa epäjatkuvalta ja näennäisen irrationaaliselta, koska ajattelutapa ja maailmankuva poikkeavat totutusta sekä muuttuvat ja kehittyvät jatkuvasti:

"Kyllähän tämmönen oman ajattelun kehittyminen, ni se on kyllä vaarallista, vanhemmat pitää sitä vaarana, mistä me ollaan varmaan kritiikkiä saatu, niinkun ansiottomasti, että eibän me haluta ketään vanhempiaan vastaan kasvattaa."

"Tämmönen innovaation ja undistuksen tarve."

"Kysytään vanhemmilta minkä tyyppistä toimintaa ne baluu."

Koulun pedagogisesti perusteltu toimintaajatus (ks. edellä koulun pedagoginen näkemys) poikkeaa perinteisestä luokkahuoneopetuksesta: "Kyllä varmaan tää pedagoginen puoli on varmaan kaikkein yhdistävin tekijä tässä koulussa."

- Kokonaisuutena kyse on laadullisesta, moniulotteisesta ja monimuuttujaisesta muutoksesta:

"Pois kaikei rajaavat linjankset."

On tietysti määrittely- ja rajanvetokysymys, koska voidaan puhua toisen asteen muutoksesta. Uudenaikaisemman koulun muutosta voidaan kuitenkin perustellusti nimittää toisen asteen muutokseksi. Perinteisessä koulussa oli myös havaittavissa muutoksen merkkejä, nimenomaan ensi asteen muutoksesta. Tässä yhteydessä en puutu perinteisen koulun muutosprosesseihin, koska kiinnostus kohdistuu toisen asteen muutokseen.
Vaikuttaa siltä, että uudemman koulun kulttuurinmuutos tuki oppimisen eli koulutuksen laadun kehittymistä. Toisen asteen muutos ei kuitenkaan automaattisesti tarkoita, että koulutuksen laatu kohenee, mutta tässä tapauksessa yhteys on ilmeinen. Kuten jo edellä totesin, ensisijaisena tutkimuskohteenani ei ollut organisaatiokulttuurin muutos, joten koulutuksen laadun ja toisen asteen muutoksen analysointi vaatisi lisäaineistoja ja laajempaa näkökulmaa. Kun koulutuksen laatu määritellään oppimisena, pitäisi tutkia oppimista ja sen tehostumista. Tähän kysymykseen ei tämän aineiston puitteissa ole mahdollista vastata.

Kaiken kaikkiaan organisaatiokulttuurin näkökulma oli hedelmällinen lähtökohta koulujen tutkimiseen. Kouluista todella oli löydettävissä organisaatiokulttuuri, joka vaikutti siihen miten koulut toimivat, opettajat käyttäytyivät ja oppilaat työskentelivät.

\section{Lopuksi}

Artikkelissa tarkasteltiin koulutusta ja koulutuksen laatua organisaatiokulttuurisesta näkökulmasta. Organisaatiokulttuuriparadigma osoittautui varsin hajanaiseksi, mikä vaikeutti organisaatiokulttuurin määrittelyä. On oikeampaa puhua teorioiden ja näkökulmien ryppäästä, kuin yhdestä teoriasta. Tämä heijastui myös koulutuksen laadun tarkasteluun. Koulutuksen laatu määriteltiin oppimiseksi, mikä ei suinkaan ole ongelmaton lähtökohta. Se tarjoaa kuitenkin yhden relevantin näkökulman koulutuksen laadun ongelmaan. Koulutuksen laadun kehittäminen edellyttää monissa oppilaitoksissa ja koulutusmuodoissa organisaation syvällistä muutosta. Organisaation syvällisessä muutoksessa painotan toisen asteen muutosta, jolla tarkoitan koko kulttuurisen viitekehyksen muuttumista.

Koulun organisaatiokulttuurin empiirisessä tutkimuksessa olen soveltanut Scheinin organisaatiokulttuuriteoriaa. Scheinin teoria tietyin muutoksin osoittautui toimivaksi ja käyttökelpoiseksi. Scheinin teoriaa kuten koko organisaatiokulttuuriparadigmaa kohtaan voidaan 
esittää perusteltua kritiikkiä. Ensisijainen ongelma koskee toiminnan ja toimijoiden analyysin puutetta. Usein toimijat on oletettu organisaatiokulttuurille alisteisiksi. Organisaatiokulttuuri voidaan kuitenkin nähdä toimijoiden tuottamana, koska on ilmeistä, että toimijat aktiivisesti tulkitsevat kulttuuria ja pyrkivät tekemään oman toimintansa organisaatiokulttuurin kannalta ymmärrettäväksi. Esitetyn kritiikin pohjalta sosiaalinen konstruktionismi ja diskurssianalyysi (ks. esimerkiksi Burr 1995) tarjoavat lupaavia näköaloja organisaatiokulttuurin teoreettisessa ja metodologisessa kehittämisessä.

Koulutuksen laatukeskustelussa on syytä muistaa, että organisaatiokulttuurinäkökulma ei tarjoa helppoja ratkaisuja, mutta sen tarjoamat näkökulmat lisäävät muutoksen onnistumisen mahdollisuutta. Koulutuksen laadun kehittäminen ja organisaatiokulttuurin muutosprosessi pitäisi aloittaa selvittämällä, millaista kulttuuri on koulutuksen eri sektoreilla. Vasta tämän jälkeen voidaan pohtia päämääriä ja niitä keinoja, joilla laatu on koulutuksessa saavutettavissa. Tämä on erityisen tärkeä huomio aikuiskoulutuksen näkökulmasta, koska aikuiskoulutuksessa on hyvin monentyyppistä koulutusta. Olisi paneuduttava erilaisten koulutusmuotojen organisaatiokulttuureihin ja kehitettävä laatua kunkin koulutusmuodon omista lähtökohdista. Ottamalla huomioon kunkin koulutusmuodon historia ja erityispiirteet, päästään laadun tavoittelussa varmasti parempiin tuloksiin.

\section{Iäntect}

Aikuiskasvatus 4/1993 (teemanumero Laatu ja aikuiskasvatus)

ALVESSON, M. (1991) Concepts of organizational culture and presummed links to efficiency. Hallinnon tutkimus 3, 181-191.

ALVESSON, M. \& BERG, P.(1988) Företagskultur och organisationssymbolism. Lund: Studentlitteratur.

BURR, V. (1995) An Introduction to Social Constructionism. London: Routledge.

FROST, P., MOORE, L., LOUIS, M., LUNDBERG,
C. \& MARTIN, J. (1991)(toim.) Reframing Organizational Culture. Newbury Park: Sage Publications.

JUUTI, P. (1994) Yrityskulttuurin murros. 2. painos. Tampere: Aavaranta.

JUUTI, P. \& LINDSTRÖM, K. (1995) Postmoderni ajattelu ja organisaation syvällinen muutos. Helsinki: Työterveyslaitos \& Johtamistaidon Opisto JTO.

KEKÄLE, J. (1993) Organisaatiokulttuurin tutkimuksen kolme näkökulmaa. Psykologia 5, 320327.

KEKÄLE, J. (1997) Leadership Cultures in Academic Departments. Joensuun yliopiston yhteiskuntatieteellisiä julkaisuja n:o 26. Joensuu.

KINNUNEN, J. (1990) Terveyskeskuksen organisaatiokulttuuri. Kuopio: Kuopion yliopisto.

MATIKAINEN, J. (1997) Koulujen kaksi maailmaa: Kabden ala-asteen organisaatiokulttuurinen tarkastelu. Visionääri, tulossa.

SAHLBERG, P. \& LEPPILAMPI (1994) Yksinään vai ybteisvoimin? Yhdessäoppimisen mabdollisuuksia etsimässä. Helsingin yliopisto, Vantaan täydennyskoulutuslaitos. Yliopistopaino.

SARALA, U. \& SARALA, A. (1996) Oppiva organisaatio - oppimisen, laadun ja tuottavuuden ybdistäminen. Tampere: Helsingin yliopiston Lahden tutkimus- ja koulutuskeskus.

SCHEIN, E. H. (1987) Organisaatiokulttuuri ja jobtaminen. Espoo: Weilin+Göös.

SENGE, P. (1990) The Fifth Discipline -The art and practise of the learning organization. New York: Doubleday.

SILÉN, T. (1995) Organisaatiokulttuuri ja jobtaminen: Kabden yrityksen kulttuurimuutosprosessin ja TQM-järjestelmän soveltamisen tarkastelu. Helsinki: Yliopistopaino.

STÅHLE, P. (1993) TQM - lisää laatua opetukseen. Aikuiskasvatus 4/1993, 233-237.

SYRJÄNEN, E. (1994) Koulukohtainen opetussuunnitelma ja koulukulttuurin muntos. Opettajankoulutuslaitos tutkimuksia 134. Helsinki: Yliopistopaino.

VESALA, K.M. (1996) Yrittäjyys ja individualismi. Sosiaalipsykologian laitoksen tutkimuksia 2/ 1996. Helsinki: Yliopistopaino.

Artikkeli on saapunut toimitukseen 15.3.1996. Se hyväksyttiin julkaistavaksi toimituskunnan kokouksessa 22.8.1997. 